\title{
GENETIC DIVERSITY IN SOME WHEAT LANDRACES FOR SOME QUALITATIVE TRAITS AND PROTEIN FINGER PRINTING
}

\author{
A.A. Hassan " ; E. E. Hassan "; R.M. Fahmy ${ }^{* * *}$ and Abdelsalam,S.E ${ }^{* *}$ \\ *Department of Plant Production, Faculty of Technology and Development , \\ Zagazig University, Egypt \\ **Genetic Resources Dept. Field . Crops . Research. Institute A.R.C. , Egypt
}

\begin{abstract}
This experiment were conducted in Genetic Resources Research, Dept. FCR .ARC. Bahteem Research Station in 2015/2016 and 2016/2017 seasons; to using some genetic diversity parameters to evaluate wheat germplasm using varies methods. The results showed that the morphological character of wheat have a special role in determining the importance of each character for increasing yield.

Landraces and obsoleted a different species can be considered as availed portion of the gene pool. They proved to have a broader genetic base concerning, flag leaf anthocyanin coloration of auricles in the accessions No.1, 6, 7, 8,9and 10, this character is a unique marker distinguish durum germplasm, also showed that the dye of anthocyanin was associated with the seeding in durum until eleven days.This information would be have a value to the plant breeder for select the superior type for further testing. Proteins sodium dodecyl sulphate polyacrylamide gel electrophoresis (SDS-PAGE) was used for each species and scored the presence or absence of each band was noted and entered in a binary data matrix. The overall results showed a low degree of heterogeneity; however different species revealed a differential protein banding pattern.
\end{abstract}

Conclusively, these results indicates that SDS-PAGE analyses of different species protein is useful to evaluate the genetic variability and different species identification, which can help in wheat breeding program.

Key words. Genetic diversity, Landraces, Qualitative, Protein Finger Printing.

\section{INTRODUCTION}

Wheat is one of the most important and widely cultivated crops in the world, today most wheat grown is hexaploid, used for bred making and 
other baked products (Debasis and Khurana, 2001). Genetic diversity is created by the nature and genetic recombination added by plant breeders for the varietal improvement,(Singh et al., 2006). The knowledge of genetic diversity in a crop species is fundamental to its improvement. An assessment of the nature and magnitude of diversity among the genotypes will help to choose the better parents for hybridization. Bread wheat plays a major role among the few crop species, being widely grown as food sources and was likely a central point to the beginning of agriculture.

Morphological characters of wheat have a special role in determining the importance of each trait in breeding programs which at least led to improving the yield and introducing commercial varieties (Mollasadeghi et al., 2011). Wheat yield is affected by many factors; genetic, environment and their interaction. The value of yield varied in dependence of yield attributes, such as stem height, leaf area, spike length, number of spikelets per spike and number of kernels per spike were also found associated with the vegetative growth period (Knezevic et al., 2012).

The proteins of seed storage for wheat consider important sources of food and energy, being also involved in the determin the quality of bread making (Cooke and Law,1998). Acrylamide gel electrophoresis sodium dodecyl sulphate has become one of the most widely used techniques to separate and characterize the proteins in storage wheat (Bietz and wall, 1972) .They reported that two types of glutenin subunits were present in the wheat grains with both of low molecular weight (LMW)( 10-70 KDa) and high molecular weight (HMW) glutenin subunits (80-130 KDa). The polyacrylamide gel electrophoresis has been used to show the different size of variation which exists between LMW and HML gluten in subunits and it has been suggested that deletions and insertion wit in the repetitive region are responsible for these variations with different length (Benmoussa et al., 2000).

Therefore, the objective of this study was estimate the genetic diversity among wheat germplasm using various methods, the difference determine through in , morphological and protein finger printing were useful in the genetic purity of different wheat germplasm through identification the desirable genotypes for further utilization in plant breeding.

\section{MATERIALS AND METHODS}

The materials in the present study comprised of thirty wheat accessions as shown in Table (1). The thirty germplasm accessions were 
Table (1): List of wheat species and landraces used in the study.

\begin{tabular}{|c|c|c|c|c|}
\hline $\begin{array}{c}\text { Serial } \\
\text { No }\end{array}$ & Locations & Species & $\begin{array}{c}\text { Chromosome } \\
\text { No. }\end{array}$ & Origen \\
\hline 1 & $\begin{array}{c}\text { Sinai-Berar Allahfan } \\
\text { (383) }\end{array}$ & $\begin{array}{l}\text { Triticum } \\
\text { aestivum }\end{array}$ & $2 n=42$ & Egypt \\
\hline 2 & $\begin{array}{c}\text { Sinai-Berar Allahfan } \\
\text { (392) }\end{array}$ & $\begin{array}{l}\text { Triticum } \\
\text { aestivum }\end{array}$ & $2 n=42$ & Egypt \\
\hline 3 & $\begin{array}{l}\text { Sinai-Al-gora Al- } \\
\text { Arish }(430)\end{array}$ & $\begin{array}{l}\text { Triticum } \\
\text { aestivum }\end{array}$ & $2 n=42$ & Egypt \\
\hline 4 & $\begin{array}{l}18 \mathrm{~km} \text { Marsa Matroh } \\
\text { Salom high way (421) }\end{array}$ & $\begin{array}{l}\text { Triticum } \\
\text { aestivum }\end{array}$ & $2 n=42$ & Egypt \\
\hline 5 & $\begin{array}{l}\text { 20km Marsa Matroh } \\
\text { Salom high way(387) }\end{array}$ & $\begin{array}{l}\text { Triticum } \\
\text { aestivum }\end{array}$ & $2 n=42$ & Egypt \\
\hline 6 & $\begin{array}{l}\text { Introduction(12) } \\
\text { (ICRDA) }\end{array}$ & $\begin{array}{l}\text { Triticum } \\
\text { durm }\end{array}$ & $2 \mathrm{n}=28$ & ICRDA \\
\hline 7 & $\begin{array}{l}\text { Introduction(13) } \\
\text { (ICRDA) }\end{array}$ & $\begin{array}{l}\text { Triticum } \\
\text { durm }\end{array}$ & $2 \mathrm{n}=28$ & ICRDA \\
\hline 8 & Introduction(14)(ICRDA) & $\begin{array}{l}\text { Triticum } \\
\text { durm }\end{array}$ & $2 \mathrm{n}=28$ & ICRDA \\
\hline 9 & $\begin{array}{c}\text { Introduction(20)CIMMY } \\
\mathrm{T} \\
\end{array}$ & $\begin{array}{c}\text { Triticum } \\
\text { durm }\end{array}$ & $2 \mathrm{n}=28$ & CIMMYT \\
\hline 10 & $\begin{array}{l}\text { Introduction(21) } \\
\text { (CIMMYT) }\end{array}$ & $\begin{array}{l}\text { Triticum } \\
\text { durm }\end{array}$ & $2 \mathrm{n}=28$ & CIMMYT \\
\hline 11 & $\begin{array}{c}\text { ASSIUT } \\
(2908) \\
\end{array}$ & $\begin{array}{l}\text { Triticum } \\
\text { aestivum }\end{array}$ & $2 n=42$ & Egypt \\
\hline 12 & $\begin{array}{c}\text { ASSIUT } \\
(2979)\end{array}$ & $\begin{array}{l}\text { Triticum } \\
\text { aestivum }\end{array}$ & $2 n=42$ & Egypt \\
\hline 13 & ASSIUT (2990) & $\begin{array}{l}\text { Triticum } \\
\text { aestivum }\end{array}$ & $2 n=42$ & Egypt \\
\hline 14 & $\begin{array}{c}\text { ASSIUT } \\
(3101)\end{array}$ & $\begin{array}{l}\text { Triticum } \\
\text { aestivum }\end{array}$ & $2 n=42$ & Egypt \\
\hline 15 & $\begin{array}{c}\text { Genetic stock } \\
(1080)\end{array}$ & $\begin{array}{l}\text { Triticum } \\
\text { aestivum }\end{array}$ & $2 n=42$ & Egypt \\
\hline 16 & $\begin{array}{c}\text { ASSIUT } \\
(2795)\end{array}$ & $\begin{array}{l}\text { Triticum } \\
\text { aestivum }\end{array}$ & $2 n=42$ & Egypt \\
\hline 17 & $\begin{array}{l}\text { ASSIUT } \\
(2801)\end{array}$ & $\begin{array}{l}\text { Triticum } \\
\text { aestivum }\end{array}$ & $2 n=42$ & Egypt \\
\hline 18 & $\begin{array}{c}\text { Genetic stock } \\
(3201)\end{array}$ & $\begin{array}{l}\text { Triticum } \\
\text { aestivum }\end{array}$ & $2 n=42$ & Egypt \\
\hline 19 & $\begin{array}{c}\text { Genetic stock } \\
\text { (3292) }\end{array}$ & $\begin{array}{l}\text { Triticum } \\
\text { aestivum }\end{array}$ & $2 n=42$ & Egypt \\
\hline 20 & Genetic stock & Triticum & $2 n=42$ & Egypt \\
\hline
\end{tabular}




\begin{tabular}{|c|c|c|c|c|}
\hline & (3237) & aestivum & & \\
\hline 21 & $\begin{array}{l}\text { ASSIUT } \\
(2968)\end{array}$ & $\begin{array}{l}\text { Triticum } \\
\text { aestivum }\end{array}$ & $2 n=42$ & Egypt \\
\hline 22 & $\begin{array}{c}\text { Genetic stock } \\
(1053)\end{array}$ & $\begin{array}{l}\text { Triticum } \\
\text { aestivum }\end{array}$ & $2 n=42$ & Egypt \\
\hline 23 & $\begin{array}{c}\text { Genetic stock } \\
(1054)\end{array}$ & $\begin{array}{l}\text { Triticum } \\
\text { aestivum }\end{array}$ & $2 n=42$ & Egypt \\
\hline 24 & $\begin{array}{c}\text { Genetic stock } \\
\text { (1057) }\end{array}$ & $\begin{array}{l}\text { Triticum } \\
\text { aestivum }\end{array}$ & $2 n=42$ & Egypt \\
\hline 25 & $\begin{array}{c}\text { Genetic stock } \\
(1060)\end{array}$ & $\begin{array}{l}\text { Triticum } \\
\text { aestivum }\end{array}$ & $2 n=42$ & Egypt \\
\hline 26 & $\begin{array}{c}\text { Genetic stock } \\
(3420)\end{array}$ & $\begin{array}{l}\text { Triticum } \\
\text { aestivum }\end{array}$ & $2 n=42$ & Egypt \\
\hline 27 & $\begin{array}{c}\text { Giza (168) } \\
\text { local variety }\end{array}$ & $\begin{array}{l}\text { Triticum } \\
\text { aestivum }\end{array}$ & $2 n=42$ & Egypt \\
\hline 28 & $\begin{array}{c}\text { Seds (12) } \\
\text { local variety }\end{array}$ & $\begin{array}{l}\text { Triticum } \\
\text { aestivum }\end{array}$ & $2 n=42$ & Egypt \\
\hline 29 & $\begin{array}{l}\text { Beni sweif (1) } \\
\text { local variety }\end{array}$ & $\begin{array}{l}\text { Triticum } \\
\text { durm }\end{array}$ & $2 n=28$ & Egypt \\
\hline 30 & $\begin{array}{l}\text { Beni sweif (6) } \\
\text { local variety }\end{array}$ & $\begin{array}{l}\text { Triticum } \\
\text { durm }\end{array}$ & $2 n=28$ & Egypt \\
\hline
\end{tabular}

SDS-protein electrophoresis:

obtained from the Genetic Resources Research Dept., Field Crops Research Institute (FCRI), Agricultural Research Center (ARC). The experiment was conducted in two seasons, of 2016/2017and 2017/2018, at Bahteem Research Station in a randomized complete blocks design with three replications. Each experimental plot consisted of four rows for each entry, $4 \mathrm{~m}$ long and $20 \mathrm{~cm}$ width. Spacing between the plants within row was kept at $5 \mathrm{~cm}$.

All other agronomic practices were applied according to recommendations for wheat program. Coleoptile anthocyanin coloration, plant growth habit, flag leaf anthocyanin coloration of auricles plant. Frequency of plant with recurred flag leaves, flag leaf glaucosity of sheath, ear glauosity, culm glaucosity of neck, awns or curs and ear density were measurements as recommended scales that reported by IBGR (1985). For miniscale preparations of all thirty genotypes in wheat samples, $0.3 \mathrm{mg}$ of leaf tissue (10 Days old) were grinded with phosphate buffer ( $\mathrm{pH}: 7)$ and pelted down then only 20ul with (80 ug) protein concentration was added to equal volume of Laemmli Sample 
Buffer, $5 \mu \mathrm{l}$ of $10 \% \operatorname{SDS}$ and $5 \mu \mathrm{l}$ of $\beta$-mercaptoethanol then boiling the mixture for $5 \mathrm{~min}$ and centrifugation 12000RPMfor 10 minutes to obtain the supernatant which contains protein fractionations. Sodium dodecyl sulphate-polyacrylamide gel electrophoresis (SDS-PAGE) was performed according to the method of Laemmli (1970). Samples prepared by adding Protein fractionation electrophoresis was performed on $12 \%$ acrylamide gel using the apparatus manufactured by BioRad. Gels were analyzed using Total Lab TL100.

\section{Data analysis}

The photographs of SDS-PAGE gel was used to study the protein profile of the all accessions. The bands were designated on the basis of their molecular weight. The presence of protein band was scored as (+)positive and its absence(-)negative as shown in (Table 3-5 ) only bright, clearly distinguishable bands were used in genetic analysis.

\section{RESULTS AND DISCUSSIONS}

The results revealed a significant variation among most of morphological characters in the different species in wheat germplasm . The range of variation observed among the germplasm for nine morphological characters are presented in Tables (2A, 2B and 2C) .Variation among germplasm was observed for coleoptile anthocyanin coloration, plant growth habit, flag leaf anthocyanin coloration of auricles of the plant. Frequency of plants with recurved, flag leaves, flag leaf glaucosity of sheath, ear glauosity, culm glaucosity of neck, ear density and awns or curs.

Wheat morphological of have a special role in determining the importance of each trait in increasing yield. Improvement based on breeding concept and use the large number of germplasm and best cultivar as a parent. The success in breeding program is not each because their were complex relationships between grain yield and it is yield components.The wheat yield is affected by many factors; genetic, environment and the interaction between genetic and environmental conditions (Epigenetic system). 
Table( 2A). Morphological characters of different studied species in wheat during 2016/2017 and 2017/ 2018growing seasons.

\begin{tabular}{|c|c|c|c|c|}
\hline $\begin{array}{l}\text { Accession } \\
\text {.No. }\end{array}$ & $\begin{array}{c}\text { Coleoptile } \\
\text { anthocyanin } \\
\text { coloration }\end{array}$ & $\begin{array}{l}\text { Plant } \\
\text { growth } \\
\text { habit }\end{array}$ & $\begin{array}{c}\text { Flag leaf } \\
\text { anthocyanin } \\
\text { coloration }\end{array}$ & $\begin{array}{c}\text { Plant. frequency } \\
\text { of plant with recurved } \\
\text { flag leaves }\end{array}$ \\
\hline 1 & $\begin{array}{c}\text { Absent } \\
\text { (very weak) }\end{array}$ & Erect & $\begin{array}{c}\text { Absent } \\
\text { (Very weak) }\end{array}$ & medium \\
\hline 2 & $\begin{array}{c}\text { Absent } \\
\text { (very weak }\end{array}$ & Erect & $\begin{array}{c}\text { Absent } \\
\text { (Very weak) }\end{array}$ & Medium \\
\hline 3 & $\begin{array}{c}\text { Absent } \\
\text { (very weak) }\end{array}$ & Erect & $\begin{array}{c}\text { Absent } \\
\text { (Very weak) }\end{array}$ & medium \\
\hline 4 & $\begin{array}{c}\text { Absent } \\
\text { (very weak) }\end{array}$ & Erect & Weak & Medium \\
\hline 5 & $\begin{array}{c}\text { Absent } \\
\text { (very weak) }\end{array}$ & Erect & Weak & Medium \\
\hline 6 & Present & Erect & Strong & Low \\
\hline 7 & Present & Erect & Strong & Low \\
\hline 8 & Present & Erect & Strong & Low \\
\hline 9 & Present & Erect & Strong & Low \\
\hline 10 & Present & Erect & Strong & Low \\
\hline 11 & $\begin{array}{c}\text { Absent } \\
\text { (very weak) }\end{array}$ & Erect & Moderate & medium \\
\hline 12 & $\begin{array}{c}\text { Absent } \\
\text { (very weak) }\end{array}$ & Erect & Weak & medium \\
\hline 13 & $\begin{array}{c}\text { Absent } \\
\text { (very weak) }\end{array}$ & Erect & Moderate & medium \\
\hline 14 & $\begin{array}{c}\text { Absent } \\
\text { (very weak) }\end{array}$ & Erect & Weak & medium \\
\hline 15 & $\begin{array}{c}\text { Absent } \\
\text { (very weak) }\end{array}$ & Erect & Weak & medium \\
\hline 16 & $\begin{array}{c}\text { Absent } \\
\text { (very weak) }\end{array}$ & Erect & $\begin{array}{c}\text { Absent } \\
\text { (Very weak) }\end{array}$ & medium \\
\hline 17 & $\begin{array}{c}\text { Absent } \\
\text { (very weak) }\end{array}$ & Erect & Moderate & medium \\
\hline 18 & $\begin{array}{c}\text { Absent(very } \\
\text { weak) }\end{array}$ & Erect & Moderate & medium \\
\hline 19 & $\begin{array}{c}\text { Absent } \\
\text { (very weak) }\end{array}$ & Erect & Moderate & Low \\
\hline 20 & $\begin{array}{c}\text { Absent } \\
\text { (very weak) }\end{array}$ & Erect & Moderate & low \\
\hline 21 & Absent & Erect & (Absent) & medium \\
\hline
\end{tabular}




\begin{tabular}{|c|c|c|c|c|}
\hline & (very weak) & & Very weak & \\
\hline 22 & $\begin{array}{c}\text { Absent } \\
\text { (very weak) }\end{array}$ & Erect & $\begin{array}{c}\text { (Absent) } \\
\text { Very weak }\end{array}$ & low \\
\hline 23 & $\begin{array}{c}\text { Absent } \\
\text { (very weak) }\end{array}$ & Erect & Weak & medium \\
\hline 24 & $\begin{array}{c}\text { Absent } \\
\text { (very weak) }\end{array}$ & Erect & $\begin{array}{c}\text { Absent } \\
\text { (Very weak) }\end{array}$ & medium \\
\hline 25 & $\begin{array}{c}\text { Absent } \\
\text { (very weak) }\end{array}$ & Erect & Strong & medium \\
\hline 26 & $\begin{array}{c}\text { Absent } \\
\text { (very weak) }\end{array}$ & Erect & Weak & medium \\
\hline 27 & $\begin{array}{c}\text { Absent } \\
\text { (very weak) }\end{array}$ & Erect & Strong & medium \\
\hline 28 & $\begin{array}{c}\text { Absent } \\
\text { (very weak) }\end{array}$ & $\begin{array}{l}\text { Semi } \\
\text { erect }\end{array}$ & Strong & low \\
\hline 29 & Present & $\begin{array}{l}\text { Semi } \\
\text { erect }\end{array}$ & Weak & medium \\
\hline 30 & Present & $\begin{array}{l}\text { Semi } \\
\text { erect }\end{array}$ & Strong & low \\
\hline
\end{tabular}

Table (2B): Morphological characters of different studied species in wheat during 2016/2017 and 2017/ 2018growing seasons.

\begin{tabular}{|c|c|c|c|}
\hline $\begin{array}{c}\text { Accession } \\
\text { No. }\end{array}$ & $\begin{array}{c}\text { Flag leaf } \\
\text { glaucosity } \\
\text { of sheath }\end{array}$ & $\begin{array}{c}\text { Ear } \\
\text { glaucosity }\end{array}$ & $\begin{array}{c}\text { glum } \\
\text { glaucosity } \\
\text { of neck }\end{array}$ \\
\hline 1 & Very weak & Very weak & Absent or very weak \\
\hline 2 & Very weak & Very Weak & Absent or very weak \\
\hline 3 & Very weak & Very Weak & Absent or very weak \\
\hline 4 & Very weak & Very Weak & Absent or very weak \\
\hline 5 & Very weak & Very Weak & Strong \\
\hline 6 & Very strong & Strong & Strong \\
\hline 7 & Very strong & Strong & Strong \\
\hline 8 & Very strong & Strong & Strong \\
\hline 9 & Very strong & Strong & Strong \\
\hline 10 & Very strong & Very strong & Very strong \\
\hline 11 & Very weak & Very Weak & Weak \\
\hline 12 & Very weak & Very Weak & Medium \\
\hline 13 & Very weak & Very Weak & Absent or very weak \\
\hline 14 & Weak & Very Weak & Medium \\
\hline 15 & Weak & Strong & Strong \\
\hline 16 & Medium & Medium & Strong \\
\hline 17 & Weak & Very weak & Weak \\
\hline
\end{tabular}


HASSAN et al.

\begin{tabular}{|c|c|c|c|}
\hline 18 & Weak & Medium & Weak \\
\hline 19 & Weak & Weak & Weak \\
\hline 20 & Medium & Medium & Weak \\
\hline 21 & Very weak & Very Weak & Medium \\
\hline 22 & Weak & Medium & Medium \\
\hline 23 & Weak & Medium & Weak \\
\hline 24 & Medium & Weak & Weak \\
\hline 25 & Weak & Weak & Absent or very weak \\
\hline 26 & Very weak & Very weak & Absent or very weak \\
\hline 27 & Very weak & Very Weak & weak \\
\hline 28 & Very weak & Very Weak & Strong \\
\hline 29 & Very weak & Very Weak & Medium \\
\hline 30 & Very weak & &
\end{tabular}

Table ( 2C). Morphological characters of different studied species in wheat during 2016/2017 and 2017/ 2018growing seasons.

\begin{tabular}{|c|c|c|}
\hline Accession No. & Awns or curs & Spikelet \\
\hline 1 & Presence & Lax \\
\hline 2 & Presence & intermediate \\
\hline 3 & Presence & Dense \\
\hline 4 & Presence & intermediate \\
\hline 5 & Presence & Intermediate \\
\hline 6 & Presence & Very dense \\
\hline 7 & Presence & Very dense \\
\hline 8 & Presence & Very dense \\
\hline 9 & Presence & Very dense \\
\hline 10 & Presence & Very dense \\
\hline 11 & Absent & Intermediate \\
\hline 12 & Presence & Intermediate \\
\hline 13 & Presence & Intermediate \\
\hline 14 & Presence & Intermediate \\
\hline 15 & Presence & Intermediate \\
\hline 16 & Presence & Intermediate \\
\hline 17 & Presence & Dense \\
\hline 18 & Presence & Intermediate \\
\hline 19 & Presence & Dense \\
\hline 20 & Presence & Very dense \\
\hline 21 & Presence & Intermediate \\
\hline
\end{tabular}




\begin{tabular}{|c|c|c|}
\hline 22 & Presence & Lax \\
\hline 23 & Presence & Very dense \\
\hline 24 & Presence & Lax \\
\hline 25 & Presence & Intermediate \\
\hline 26 & Presence & Intermediate \\
\hline 27 & Presence & Very dense \\
\hline 28 & Presence & Very dense \\
\hline 29 & Presence & Very dense \\
\hline 30 & Presence & Very dense \\
\hline
\end{tabular}

The present study was designed to find out the definite-distinguished characters of wheat (landraces, collected from different areas in Egypt and five lines from (ICRDA and CIMMYT) in addition to check varieties (local variety) in bread wheat (Triticum aestivum and Triticum durm ) under study. Breeders need information to the field in specter. The breeders require these data for evaluation the genetic sources of their program.

In addition, it serves as a true witness in the course of breeder's right implementation. Field inspectors should have recognizable characters of the specific landrace, in addition, introduce and two cheek variety (local variety) under inspection spp that such standard of purity might be worked out properly. This could be carried out directly in the field or by taking sample for laboratory analyses. Certain morphological characters and protein SDS-PAGE aspects that needed to studied the furnish necessary data, in this respect.

Characterization of wheat under environmental conditions in Egypt, the value of nine traits was obtained for thirty accessions in the two seasons. The landraces usually have a breeder genetic base and can therefore prove an important valuable characteristics for breeding landraces and obsolete cultivars can be considered as a valuable portion and gene pool. Usually have a broader genetic base, in addition introduction and two check varieties in Triticum aestivum and two cheek triticum durum, phenotypic variation was derived from genotype, environment and their interaction between genetic and environment. These results are agreement with (Chapman ,2008; Joosen et al., 2013).

The phenotypic variance of the same accession was derived from genetic, environment and interaction between genetic and environment. The results supported that variation existing the studied accessions is very important for breeding programs. The accessions revealed a wide range of 
variations for morphological characters which have a potential to determine the best accessions for different environments. The variation was detected in the morphological characters of wheat germplasm collected from different regions of Egypt.

Data in Tables (2A, 2B and 2C) indicated that the coleoptile anthocyanin coloration for all different germplasm of wheat in durum (it is very strong accessions No. 6.7,8,9 and 10. Regarding o the habit of plant growth, erect except accession No. (29) Which were semi erect. Narrow variation existed for habit of plant growth.

Concerning to the flag leaf anthocyanin coloration of auricles No.(6,7,8,9and10) had a strong anthocyanin coloration which can be used as a unique character for this accessions in this stage, while accessions No. $(1,2,3,16,21,22$ and 24$)$ were very weak, and was moderate accession No. $11,13,17,18,19$ and 20 in this germplasm.

The variation is useful trait for different germplasm identification. The frequency of plant with recurved flag leaves was classified to two groups, low and moderate. For the glancosity of sheath flag leaf classification three groups, absent (very weak), weak and moderate, the variation can be used as a unique characters for this accessions in this stage. These characters are important for the breeders in selection of promising plant material. Morphological diversity was detected for different traits in relation to regions altitudes and agro - ecological zones. These results are confirmed those obtained by (Hussein et al ., 1981) . Concerning ear glaucosity classification into five groups i,e., absent (very weak), weak ,medium ,strong and very strong .

Regarding to the glum glaucousitiy of neck, classified to six groups, i.e. Absent, very weak weak, medium strong and very strong.

Awns or scars classified to into two groups, presence and absent. These results agreement with ear density was classified to four groups, lax, intermediate, dense and very dense, Hence the variation morphological diversity in Egyptian wheat genotypes in different relation to regions and altitude zone of origin. So this study was amid to estimate morphological diversity exists among wheat accessions collected over 30 years ago.

However, the genetic variation in current Egyptian wheat germplasm has over the millennia been presented by the farmers who keep the cereal from previous harvest years. So this study was aimed to identify the different species in wheat, in determine the importance of each character under study which increase yield in wheat. 


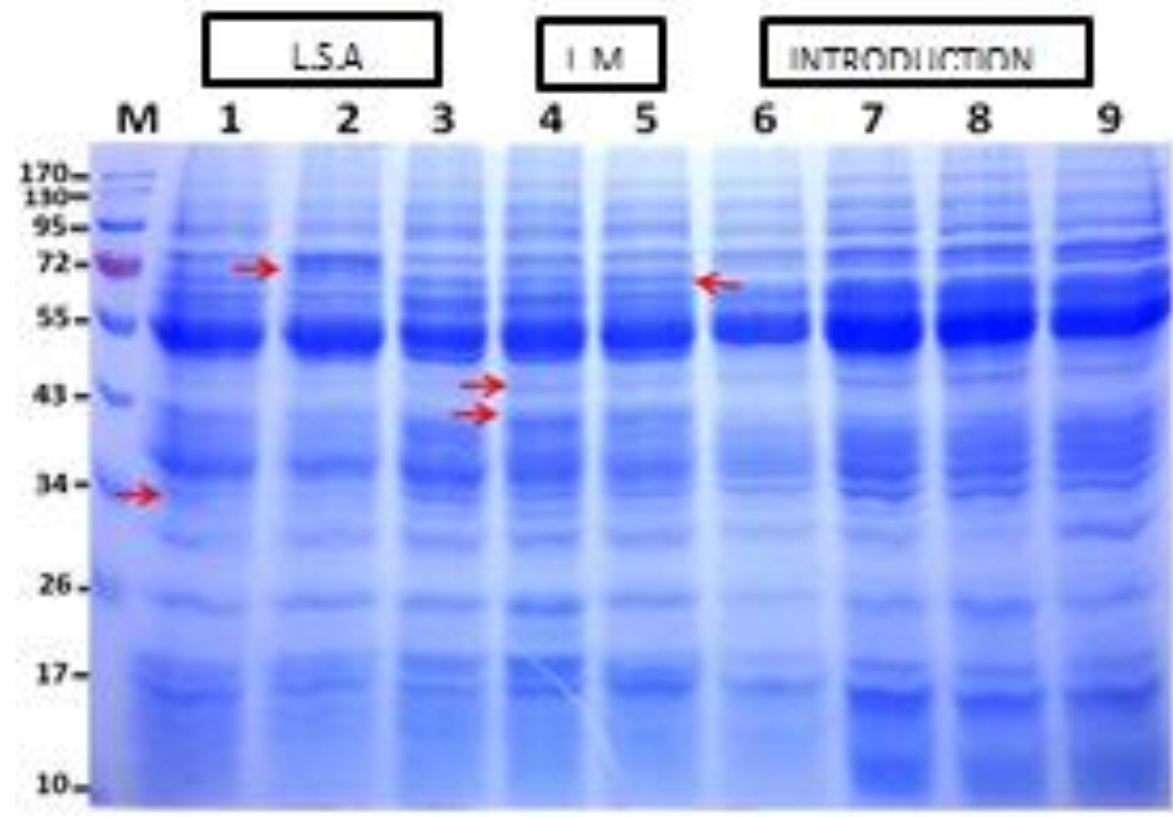

Figure(1): SDS-PACE profle of sosd storage pootsin from vbox gootypa from 1 - 9 ,

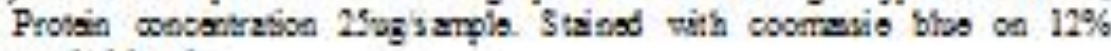
vartanidegat.

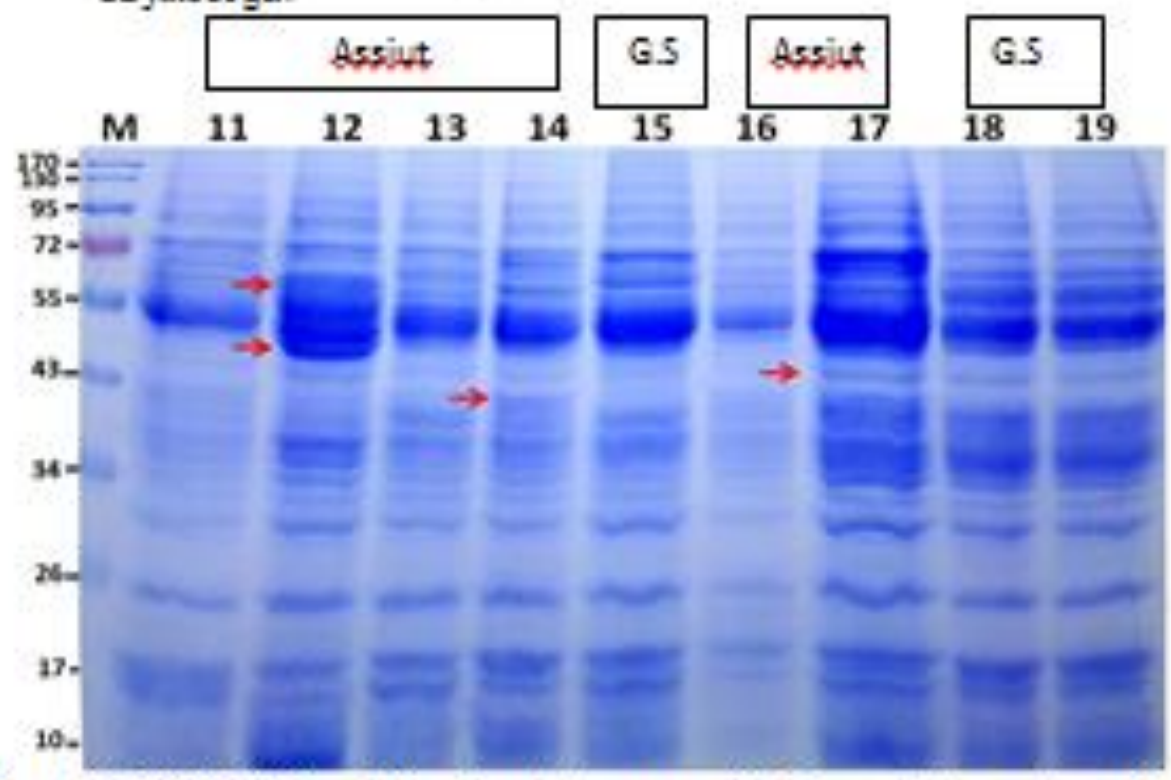

Figure (2): SDSPAGE profile of sead storage protein from wheat genotypes from 11 - 19 , Protein concentration 25 ug semple Stained with coomassis bhe on $12 \%$ acrylmide get 

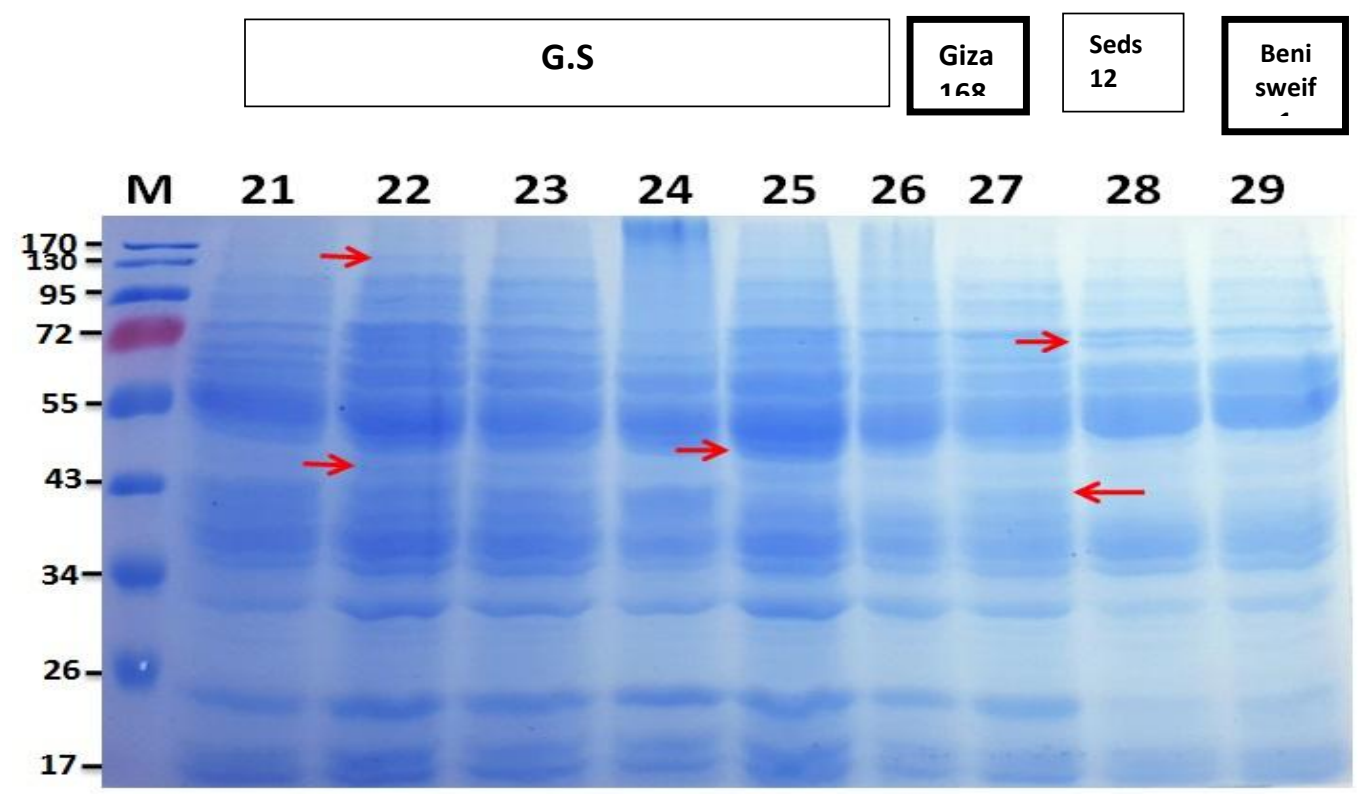

Figure (3): SDS-PAGE profile of seed storage protein from wheat genotypes from 21 - 29 Protein concentration 25ug/sample. Stained with coomassie blue on $12 \%$ acrylmide gel.

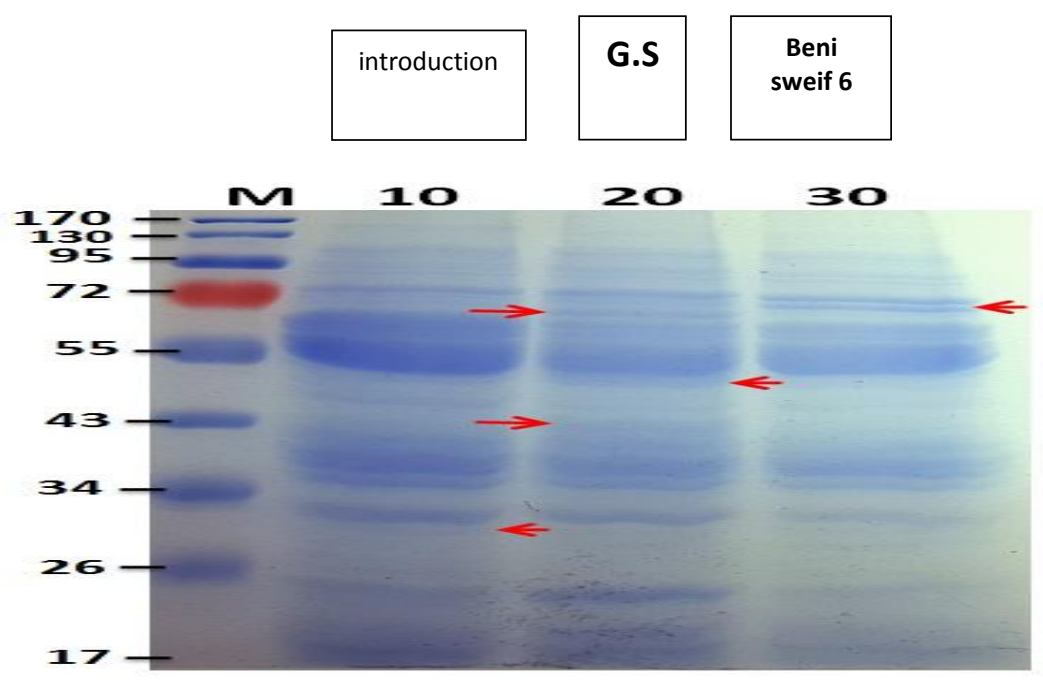

Figure(4) . Showed the SDS-PAGE profile of protein for seed storage from wheat genotypes which collected from different area of Egypt Protein concentration $25 \mathrm{ug} / \mathrm{sample}$, Stained with coomassie blue on $12 \%$ acrylmide gel. 
The accession No.1 Sinai -Bear Aullahfan (112) gave a unique marker $34 \mathrm{KD}$, while unique markers $72 \mathrm{KD}$ as polymorphism for accession No. 2 Sinai-Bera-Allahfan (1)were detected of them were polymorphic.

They also accession No. $418 \mathrm{~km}$ Mars matroh salom high way was found two unique markers $34,50 \mathrm{KD}$, also accession No. 5 give unique markers $70 \mathrm{KD}$. Distinguish in two accession collection in Mars matroh salom high way, wherever the accessions No. 1,2, 3, 4, and 5 expected one origin. Also accession No.11,12,13 and 14 collected in assiut, the accession No.12 showed two unique markers 47 and $57 \mathrm{KD}$, also accession No. 14 give unique markers $39 \mathrm{KD}$.

Regarding the accession No. 17was gave unique marker45 KD. Meanwhile accession No. 22 genetic stock (GS) give the unique markers in $45 \mathrm{KD}$ and $130 \mathrm{KD}$, also accession No. 25 give the unique marker $50 \mathrm{KD}$. Regarding to the Giza 168 local variety give unique marker 45KD, also Seds 12 local varieties give a unique marker $175 \mathrm{KD}$.

The genetic stock gave three unique markers $30 \mathrm{KD}, 34 \mathrm{KD}$ and 65KD .Also Beni-Sewif 6 gave the unique marker 70KD. Meanwhile, local variety G168 gave the unique marker 30KD.

The results in Tables (3,4 and 5) showed the highly genetic diversity among the wheat genotypes for protein bands polymorphism, where, two entries showed one polymorphism bands on the other side thirteen. The entries shoed two polymorphic bands, while six entries showed three polymorphic bands, finally nine entries showed four bands with different .Molecular weight ,72,55, 43,34 and 26 KD respectively.

Moreover ,the local variety showed highly variation where the Giza 168 local variety showed four bands with molecular weight 72, 43,34 and 26 KD respectively, the Seds (12) variety showed three with molecular weight 72,55 and $34 \mathrm{KD}$, respectively, while the Beni-Sweif 1 and 6 varieties showed the same two bands with molecular weight 55 and $34 \mathrm{KD}$ respectively, that mean could be using the total soluble proteins in desitengwish among wheat genotypes. 
Table (3): Molecular weights and polymorphic bands presence or absence in group1 genotypes of Wheat (Triticum aestivum L.)

\begin{tabular}{|l|c|c|c|c|c|c|c|c|c|c|}
\hline \multirow{2}{*}{$\begin{array}{l}\text { Band } \\
\text { MW }\end{array}$} & \multicolumn{10}{|c|}{ Genotypes } \\
\cline { 2 - 14 } & $\mathbf{2}$ & $\mathbf{3}$ & $\mathbf{4}$ & $\mathbf{5}$ & $\mathbf{6}$ & $\mathbf{7}$ & $\mathbf{8}$ & $\mathbf{9}$ & $\mathbf{1 0}$ \\
\hline $\mathbf{7 2}$ & + & +++ & + & + & ++ & +++ & +++ & +++ & +++ & + \\
\hline $\mathbf{5 5}$ & - & - & - & - & - & - & +++ & +++ & +++ & +++ \\
\hline $\mathbf{4 3}$ & - & - & - & ++ & - & - & - & - & ++ & - \\
\hline $\mathbf{3 4}$ & - & - & - & + & - & - & + & + & + & - \\
\hline $\mathbf{2 6}$ & + & + & + & + & + & - & + & + & - & + \\
\hline total & $\mathbf{2}$ & $\mathbf{2}$ & $\mathbf{2}$ & $\mathbf{4}$ & $\mathbf{2}$ & $\mathbf{1}$ & $\mathbf{4}$ & $\mathbf{4}$ & $\mathbf{4}$ & $\mathbf{3}$ \\
\hline
\end{tabular}

Table (4): Molecular weights and polymorphic bands presence or absence in group2 genotypes of Wheat (Triticum aestivum L.)

\begin{tabular}{|c|c|c|c|c|c|c|c|c|c|c|}
\hline \multirow{2}{*}{$\begin{array}{l}\text { Band } \\
\text { MW }\end{array}$} & \multicolumn{10}{|c|}{ Genotypes } \\
\hline & 11 & 12 & 13 & 14 & 15 & 16 & 17 & 18 & 19 & 20 \\
\hline 72 & + & + & + & - & + & - & ++ & - & - & + \\
\hline 55 & - & ++ & - & - & + & + & - & + & + & - \\
\hline 43 & - & - & - & + & - & - & + & + & + & + \\
\hline 34 & - & + & - & - & + & - & - & - & + & - \\
\hline 26 & + & + & + & + & + & - & + & + & + & - \\
\hline Total & 2 & 4 & 2 & 2 & 4 & 1 & 3 & 3 & 4 & 2 \\
\hline
\end{tabular}

Table (5): Molecular weights Wheat and polymorphic bands of the total protein in the third group of presence or absence of Wheat genotypes (Triticum aestivum L.)

\begin{tabular}{||c|c|c|c|c|c|c|c|c|c|c||}
\hline \multirow{2}{*}{$\begin{array}{l}\text { Band } \\
\text { MW }\end{array}$} & \multicolumn{10}{|c|}{ Genotypes } \\
\hline $\mathbf{7 2}$ & + & $\mathbf{2 2}$ & $\mathbf{2 3}$ & $\mathbf{2 4}$ & $\mathbf{2 5}$ & $\mathbf{2 6}$ & $\mathbf{2 7}$ & $\mathbf{2 8}$ & $\mathbf{2 9}$ & $\mathbf{3 0}$ \\
\hline $\mathbf{5 5}$ & + & + & - & - & - & - & - & ++ & ++ & ++ \\
\hline $\mathbf{4 3}$ & - & + & + & + & - & - & + & - & - & - \\
\hline $\mathbf{3 4}$ & - & + & + & - & + & - & + & + & + & + \\
\hline $\mathbf{2 6}$ & - & - & - & + & + & + & + & - & - & - \\
\hline Total & $\mathbf{2}$ & $\mathbf{4}$ & $\mathbf{3}$ & $\mathbf{2}$ & $\mathbf{3}$ & $\mathbf{2}$ & $\mathbf{4}$ & $\mathbf{3}$ & $\mathbf{2}$ & $\mathbf{2}$ \\
\hline
\end{tabular}


Conclusively, these results indicates that SDS -PAGE analyses of different species protein is useful to evaluate the genetic variability and different species identification, which can help in wheat breeding program.

\section{REFERENCES}

Benmoussa ,M. LP,,Vezina, M ,Page., S., Yelle and S .Laberge (2000). Genetic polymorphism in low-molecular weight glutenin genes from .Triticum aestivum, variety chines spring .Theo .APPL.Gen.,100(5) :789-793.

Bietz,Ja. and ,J.S, Wall (1972). Wheat gulten subunits molecular weights determined by sodium sulfate-polyacrylamide gel electrophoreses. Cereal chem .,49:416-430.

Chapman,S.C.,(2008).Use of crop models understand genotype by environment interactions four drought in real -world and simulated plant breeding trails. Euphytica ,16, 195-208.

Cooke.RJ, j.r, Law , (1998).Seed strobe protein diversity in wheat varieties . Plant Varieties and Seeds ,11: 159-167.

Debasis ,P. and P.Khurana (2001). Wheat biotechnology .Amin ,Review .E.J.B,4(2)1-29.

Hussein , M; A, E.S Kandil ; and M.ABD El-Alim (1981).Effect of seeding methods and nitrogen fertilizer on some agronomical characters of wheat cultivars (Triticum aestivum L. ) . Ann-Agric Sci. Moshtohor, (15) :3-12.

IBPGR (1985). International Board of plant Genetic Resources Crop Genetic Resources Center. Wheat Descriptors AGPG: IBPGR/ 85/ 210. Rome ,Italy . pp 1-19. III Proceeding of the. Third International Triticeae. Symposium .Aleppo. Syria 4-8 May, 1997. 1998 , 165-170.

Joosen ,R.V.L.,Arends,D., Li,Y., Willlems ， L.A.G., Keurent Jes ,J.J.B.,Liglerink,W., Jansen ,R.C., Hihorst. H. KK.M. (2013).Identifying genotype -by-germinating Arabidopsis seeds using generalized genetical genomics .Plant Physiol.,162.553-566.

Knezevic ,D., Z.C.V. Ecevic ., ,S Stamenkovics.. S., Atansijevic,. and .B .Milosevic (2012) .Variability of number of kernels per spike in wheat cultivars(Triticum aestivium L.)J. Central European Agri., 13 (3)607614.

Laemmli, U.K(1970) .Cleavage of structural proteins during the assembly of the head of bacteriophage T4, Nature ,227(5259):680- 685. 
Mollas adegi ,V., A.A. S, R Imani, and M. Khayatenzhad 2011).Classifying bread wheat genotypes by multivariable statistical analysis to achieve high yield under after an thesis drought .Middle East .J. Sci. Res., 7.214220.

Singh,S.K., ,B.N., Singh P.K.,Singh, and,C.L. Sharma (2006).Genetic divergence of exotic germplasm lines in wheat (T. aestinum L. ) Indian. J. Plant Genetic Resources ,19(2): 218-220.

\section{التنوع الوراثى فى بعض سلالات القمح على بعض الصفات الوصفية

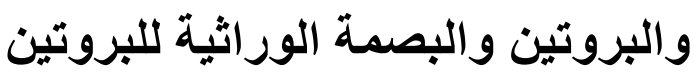

$$
\begin{aligned}
& \text { على عبد الحميد حسان (') السبد السيد حسن (') رجب محمد فهمى (r) سيد }
\end{aligned}
$$

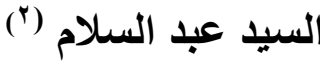

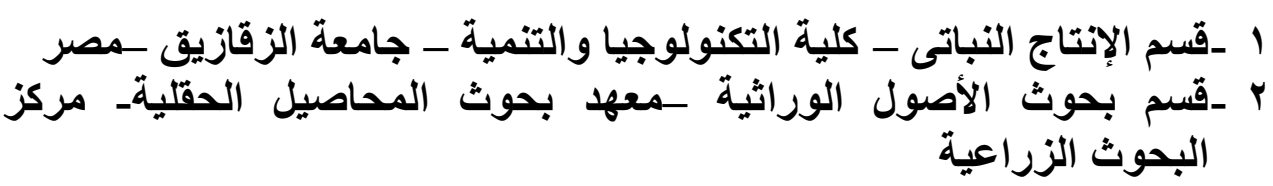

أجريت هذه الدراسة بقسم بحوث الأصول الور اثية معهذ بحوث المحاصيل الحقلة

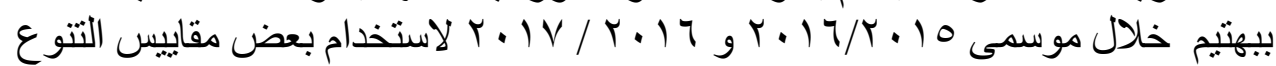

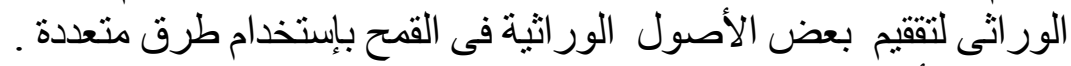

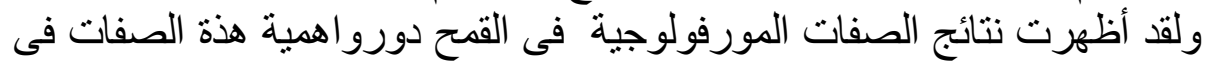

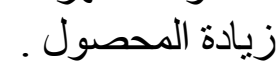

كما أظهرت السلالات الاصول تنوع للبروتين والجينات المسئولة عن أفراز هدة

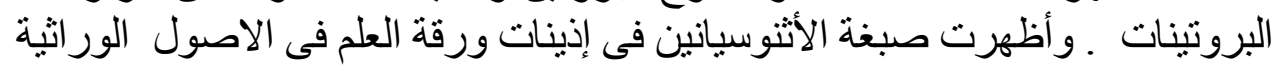

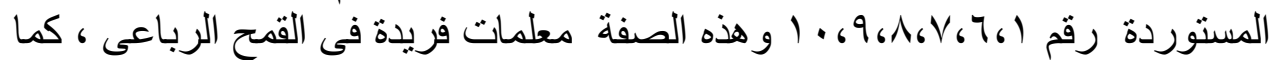

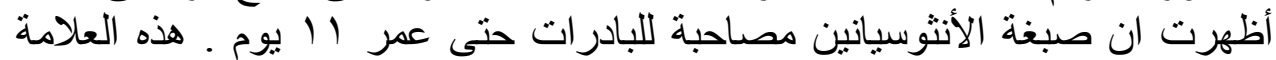

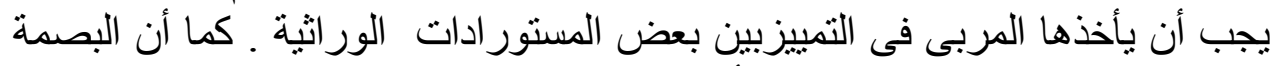

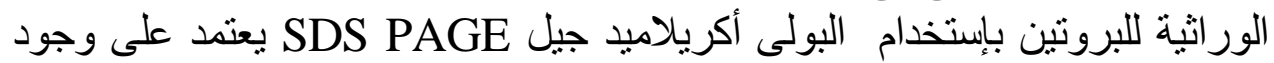
(band)

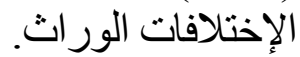
التوصية: لذا توصى الإراسة باستخدام البصمة للاصول المختلفة ور اثبا فى تقيبم الاختلافات بين الاصول الور اثية وذلك للمساعدة فى بر امج التربية لمحصول القمح. 